\title{
Faktor Yang Mempengaruhi Status Gizi Pada Balita Di Wilayah Kerja Puskesmas Paal V Kota Jambi
}

\section{Factors Affecting the Nutritional Status of Toddlers in the Work Area of the Paal V Community Health Center Jambi City}

\author{
Euis Ristanti ${ }^{1}$, Putri Sahara Harahap ${ }^{2}$, Subakir $^{3}$ \\ 1,2,3Sekolah Tinggi Ilmu Kesehatan Harapa Ibu Jambi, Jambi \\ *Koresponding Penulis : ${ }^{1}$ euisristanti1998@gmail.com
}

\begin{abstract}
ABSTRAK
Masalah gizi kurang merupakan suatu masalah gizi yang disebabkan karena kurangnya asupan gizi baik dalam jangka waktu pendek mapun panjang. Kejadian status gizi kurang di Puskesmas Paal V pada tahun 2018 sebesar 2,1\%. Penelitian ini merupakan penelitian kuantitatif dengan pendekatan case control. Tujuan penelitian ini adalah untuk mengetahui hubungan pengetahuan, partisipasi ibu dalam posyandu, pola asuh, penyakit infeksi, tingkat risiko pencemaran jamban, dan tingkat risiko pencemaran sarana air bersih dengan status gizi pada balita di wilayah kerja Puskesmas Paal V Kota Jambi. Populasi dalam penelitian ini sebanyak 32 balita kasus dan 32 balita kontrol. Sampel kasus adalah ibu yang memiliki balita dengan status gizi kurang 24 orang. Sampel kontrol adalah ibu yang memiliki balita dengan status gizi baik sebanyak 24 orang. Uji statistik yang digunakan adalah uji chi-square. Hasil penelitian diketahui bahwa \% responden memiliki balita dengan status gizi kurang, 50\% responden memiliki pengetahuan kurang baik, 97,9\% responden memiliki partisipasi dalam posyandu baik, 37,5\% responden memiliki pola asuh kurang baik, 22,9\% responden memiliki balita menderita penyakit infeksi, $52,1 \%$ responden memiliki tingkat risiko pencemaran jamban risiko sedang dan $14,6 \%$ responden memiliki tingkat risiko pencemaran sarana air bersih tingkat risiko sedang. Hasil bivariat menunjukkan ada hubungan antara pengetahuan $(\mathrm{p}=0,043 ; \mathrm{OR}=4,0)$, pola asuh $(\mathrm{p}=0,037 ; \mathrm{OR}=4,491)$, penyakit infeksi ( $\mathrm{p}=0,039 ; \mathrm{OR}=6,6)$, tingkat risiko pencemaran jamban $(\mathrm{p}=0,021$; $\mathrm{OR}=0,206$ ) dengan status gizi pada balita. Tidak ada hubungan antara partisipasi ibu dalam posyandu $(\mathrm{p}=1,000 ; \mathrm{OR}=2,043)$ dan tingkat risiko pencemaran sarana air bersih $(\mathrm{p}=1,000 ; \mathrm{OR}=1,4)$ dengan status gizi balita.
\end{abstract}

\section{Kata Kunci : Faktor Mempengaruhi Status Gizi Balita}

Abstract
Malnutrition is a nutritional problem caused by a lack of good nutrition in the
short and long term. The incidence of malnutrition in Paal V Community Helath
Center in 2018 was 2.1\%. This research is a quantitative study with a case control
approach. The purpose of this study was to determine the relationship between
knowledge of maternal participation in posyandu, parenting style, infectious
diseases, risk level of latrine pollution and the level of risk of contamination with
clean water facilities and nutrional status of children five in the work area of


Journal of Healthcare Technology and Medicine Vol. 6 No. 2 Oktober 2020

Universitas Ubudiyah Indonesia

e-ISSN : 2615-109X

Puskesmas Paal V Jambi City. The population in this study were 32 cases and 32 control children. The sample of cases is mothers who have children under five with malnutrition status 24 people. The control sample was 24 mothers who had toddlers with good nutritional status. The statistical test used was the chi-square test. The results of the study show that \% of respondents have toddlers with poor nutritional status, 50\% of respondents have poor knowledge, $97.9 \%$ of respondents have good participation in posyandu, $37.5 \%$ of respondents have poor parenting, $22.9 \%$ of respondents have toddlers suffering from an infectious disease, $52.1 \%$ of have a moderate risk level of latrine pollution and $14.6 \%$ of respondents have a moderate risk level of contamination with clean water facilities. The bivariate results showed that there was a relationship between knowledge $(p=0.043 ;$ OR $=4.0)$, parenting styles $(p=0.037 ;$ OR $=4.491)$, infectious diseases $(p=0.039 ; O R=6.6)$, the level of risk contaminating the latrine ( $p=0.021 ; O R=0.206)$ with the nutritional status of children under five. There is no relationship between maternal participation in posyandu ( $p=1,000$; $O R=2,043)$ and level of risk of contamination of clean water facilities $(p=$ 1,000; OR =1.4) and the nutritional status of children under five.

\section{Keywords: Factor affecting the nutritional status of children under five}

\section{PENDAHULUAN}

Hasil Pemantauan Status Gizi (PSG) yang diselenggarakan oleh Kementrian Kesehatan tahun 2017, yaitu persentase gizi buruk pada balita usia 0-59 bulan sebesar 3,8\% dan persentase gizi kurang 14,0\%. Provinsi dengan persentase tertinggi gizi buruk dan gizi kurang pada balita usia 0-59 bulan tahun 2017 adalah Nusa Tenggara Timur, sedangkan provinsi dengan persentase terendah adalah Provinsi Bali (Kemenkes RI, 2018).

Sedangkan di Provinsi Jambi persentase gizi kurang adalah sebesar 11,91\% sedangakan untuk gizi buruk sebesar 3,83\%. Persentase gizi kurang di Kabupaten Kerinci sebesar 14,22\%, Merangin sebesar 9,36\%, Sarolangun 5,36\%, Batang Hari 19,06\%, Muaro Jambi 10,36\%, Tanjung Jabung Timur 13,82\%, Jantung Jabung Barat 15,73\%, Tebo 11,49\%, Bungo 10,53\%, Jambi 11,71\%, Sungai Penuh 15,99\% ${ }^{1}$. Cakupan gizi kurang dan buruk di Kota Jambi pada Tahun 2018 sebanyak $325(1.1 \%)$ dan $49(0,2 \%)$ penderita.

Masalah kurang gizi adalah suatu masalah gizi yang disebabkan karena kurangnya asupan gizi baik dalam jangka waktu pendek maupun panjang. Jenis penyakit masalah kurang gizi ditentukan berdasarkan jenis zat gizi apa yang dikonsumsi, banyak juga yang terjadi masalah gizi kurang yang komplek karena 2 atau lebih zat gizi. Jenis masalah gizi kurang meliputi ; kekurangan energi protein 
Journal of Healthcare Technology and Medicine Vol. 6 No. 2 Oktober 2020

Universitas Ubudiyah Indonesia

e-ISSN : 2615-109X

(KEP), kekurangan vitamin A, gangguan akibat kekurangan yodium (GAKY), anemia, stunting, defisiensi vitamin, defisiensi mineral (Setyawati, 2018).

Status gizi mempunyai keterkaitan yang erat dengan kejadian infeksi. Anak yang mempunyai status gizi kurang, akan mudah terkena infeksi karena anak tidak mempunyai daya tahan tubuh yang cukup. Sebaliknya, anak yang menderita penyakit infeksi, umumnya tidak mempunyai nafsu makan yang cukup, akibatnya anak kekurangan gizi dan jatuh pada status gizi kurang.Jadi, keterkaitan infeksi dengan status gizi mempunyai hubungan timbal balik yang kuat.Beberapa penyakit infeksi yang terkait dengan status gizi adalah diare, TBC, cacingan, batuk rejan, dan penyakit infeksi lainnya (Par'i, 2016).

Keterbatasan pengetahuan ibu mengenai gizi akan beresiko pada kesehatan dan pertumbuhan anak, baik dalam kandungan dan perkembangannya. Hal ini diperkuat oleh penelitian (Tantejo et al, 2013) yang menyimpulkan bahwa terdapat hubungan antara pengetahuan ibu tentang gizi dengan status gizi balita dengan nilai $\mathrm{p}=0,047$. Tingkat pengetahuan gizi seseorang besar pengaruh nya bagi perubahan sikap dan perilaku dalam pemilihan bahan makanan, yang selanjutnya akan berpengaruh pula pada keadaan gizi individu yang bersangkutan (Tantejo et al, 2013).

Pola pengasuhan anak yang kurang memadai, setiap keluarga diharapkan dapat menyediakan waktu, perhatian dan dukungan terhadap anak, agar anak dapat tumbuh kembang dengan baik, baik fisik, mental maupun sosial. UNICEF (2012), kurangnya air bersih dan sanitasi lingkungan yang tidak memadai serta praktik-praktik kebersihan yang buruk adalah beberapa mendasari penyebab malnutrisi, penyakit dan kematian pada anak-anak. Jika anak mengalami diare yang disebabkan karena kurangnya air bersih atau praktek kebersihan yang buruk, maka akan menguras nutrisi tubuh (UNICEF, 2012).

Tujuan penelitian adalah untuk mengetahui faktor yang mempengaruhi status gizi pada balita di wilayah kerja Puskesmas Paal V Kota Jambi Tahun 2020.

\section{METODE PENELITIAN}


Journal of Healthcare Technology and Medicine Vol. 6 No. 2 Oktober 2020

Universitas Ubudiyah Indonesia

e-ISSN : 2615-109X

Penelitian ini merupakan penelitian Kuantitatif dengan pendekatan case control. Tujuan penelitian ini adalah untuk mengetahui faktor yang mempengaruhi status gizi pada balita di wilayah kerja Puskesmas Paal V Kota Jambi Tahun 2020. Populasi dalam penelitian ini adalah ibu beserta anak balita nya yang berusia 1 - 5 tahun yang terkena gizi kurang dan yang tidak gizi kurang.

Populasi dalam penelitian ini sebanyak 32 balita (kasus) dan 32 balita (kontrol) yang bertempat tinggal di Kelurahan Paal V Kota Jambi. Pengambilan sampel dilakukan dengan cluster random sampling (teknik yang digunakan untuk menentukan sampel bila obyek yang akan diteliti atau sumber data sangat luas). Pengumpulan data dilakukan dengan kuesioner dan pengukuran balita yang menjadi sampel penelitian.Analisis data yang digunakan adalah analisis univariat dan bivariat.

\section{HASIL DAN PEMBAHASAN}

Hasil penelitian menunjukkan bahwa sebanyak 50\% responden memiliki balita dengan status gizi kurang, 50\% responden memiliki pengetahuan kurang baik, $97,9 \%$ responden memiliki partisipasi dalam posyandu baik, 37,5\% responden memiliki pola asuh kurang baik, 22,9\% responden memiliki balita menderita penyakit infeksi, $52,1 \%$ responden memiliki tingkat risiko pencemaran jamban resiko sedang dan $14,6 \%$ responden memiliki tingkat risiko pencemaran sarana air bersih tingkat resiko sedang (Tabel 1).

Hasil bivariat menunjukkan ada hubungan antara pengetahuan $(p=0,043$; $\mathrm{OR}=4,0)$, pola asuh $(\mathrm{p}=0,037 ; \mathrm{OR}=4,491)$, penyakit infeksi $(\mathrm{p}=0,039 ; \mathrm{OR}=6,6)$, tingkat risiko pencemaran jamban $(\mathrm{p}=0,021$; $\mathrm{OR}=0,206)$ dengan status gizi pada balita. Tidak ada hubungan antara partisipasi ibu dalam posyandu $(\mathrm{p}=1,000$; $\mathrm{OR}=2,043)$ dan tingkat risiko pencemaran sarana air bersih $(\mathrm{p}=1,000 ; \mathrm{OR}=1,4)$ dengan status gizi balita (Tabel 2).

Tabel 1. Gambaran Faktor-faktor yang Berhubungan dengan Status Gizi Pada Balita di Wilayah Kerja Puskesmas Paal V Kota Jambi

\begin{tabular}{lcc}
\hline \multicolumn{1}{c}{ Variabel } & Jumlah & \% \\
\hline Pengetahuan & & \\
Kurang Baik & 24 & 50,0 \\
Baik & 24 & 50,0 \\
\hline Partipasi
\end{tabular}

Partisipasi Ibu 
Journal of Healthcare Technology and Medicine Vol. 6 No. 2 Oktober 2020

Universitas Ubudiyah Indonesia

e-ISSN : 2615-109X

\begin{tabular}{lcc} 
Kurang Baik & 1 & 2,1 \\
Baik & 47 & 97,9 \\
\hline Pola Asuh & & \\
Kurang Baik & 18 & 37,5 \\
Baik & 30 & 62,5 \\
\hline Penyakit Infeksi & & \\
Menderita Infeksi & 11 & 22,9 \\
Tidak & 37 & 77,1 \\
\hline tingkat risiko pencemaran & & \\
jamban & & \\
Sedang & 25 & 52,1 \\
Rendah & 23 & 47,9 \\
\hline tingkat risiko pencemaran & & \\
sarana air bersih & & \\
Sedang & 7 & 14,6 \\
Rendah & 41 & 85,4 \\
\hline
\end{tabular}

Tabel 2 Faktor Yang Berhubungan dengan Status Gizi Pada Balita di Wilayah Kerja Puskesmas Paal V Kota Jambi

\begin{tabular}{|c|c|c|c|c|c|c|c|c|}
\hline \multirow{3}{*}{ Variabel } & \multicolumn{4}{|c|}{ Status Gizi } & \multirow{2}{*}{\multicolumn{2}{|c|}{ Total }} & \multirow{3}{*}{ p-value } & \multirow{3}{*}{ OR } \\
\hline & \multicolumn{2}{|c|}{ Kasus } & \multicolumn{2}{|c|}{ Kontrol } & & & & \\
\hline & $\mathbf{n}$ & $\%$ & $\mathbf{n}$ & $\%$ & $\mathbf{n}$ & $\%$ & & \\
\hline Pengetahuan & & & & & & & & 4,0 \\
\hline Kurang Baik & 16 & 66,7 & 8 & 33,3 & 24 & 50,0 & \multirow{2}{*}{0,043} & $(1,205-$ \\
\hline Baik & 8 & 33,3 & 16 & 66,7 & 24 & 50,0 & & $13,283)$ \\
\hline Partisipasi Ibu & & & & & & & & 2,043 \\
\hline Kurang Baik & 1 & 4,2 & 0 & 0,0 & 1 & 2,1 & 1,000 & $(1,526-2,737)$ \\
\hline Baik & 23 & 95,8 & 24 & 100 & 47 & 97,9 & & \\
\hline \multicolumn{9}{|l|}{ Pola Asuh } \\
\hline Kurang Baik & 13 & 54,2 & 5 & 20,8 & 18 & 37,5 & \multirow[t]{2}{*}{0,037} & $4,491(1,260-$ \\
\hline Baik & 11 & 45,8 & 19 & 79,2 & 30 & 62,5 & & $16,006)$ \\
\hline Penyakit Infeksi & & & & & & & \multirow{3}{*}{0,039} & 6,6 \\
\hline Menderita & 9 & 37,5 & 2 & 8,3 & 11 & 22,9 & & $(1,246-$ \\
\hline Tidak & 15 & 62,5 & 22 & 91,7 & 37 & 77,1 & & $34,949)$ \\
\hline Tingkat Risiko & & & & & & & \multirow{5}{*}{0,021} & 0,206 \\
\hline Pencemaran & & & & & & & & $(0,061-0,669)$ \\
\hline Jamban & & & & & & & & \\
\hline Risiko Sedang & 8 & 33,3 & 17 & 70,8 & 25 & 52,1 & & \\
\hline Risiko Rendah & 18 & 66,7 & 7 & 29,2 & 23 & 47,9 & & \\
\hline Tingkat Risiko & & & & & & & & 1,4 \\
\hline Pencemaran & & & & & & & & $(0,278-7,056)$ \\
\hline Sarana Air Bersih & & & & & & & \multirow{3}{*}{1,000} & \\
\hline Risiko Sedang & 4 & 16,7 & 3 & 12,5 & 7 & 14,6 & & \\
\hline Risiko Rendah & 20 & 83,3 & 21 & 87,5 & 41 & 85,4 & & \\
\hline
\end{tabular}


Journal of Healthcare Technology and Medicine Vol. 6 No. 2 Oktober 2020

Universitas Ubudiyah Indonesia

e-ISSN : 2615-109X

Berdasarkan hasil penelitian menunjukkan ada hubungan antara pengetahuan dengan status gizi pada balita di wilayah kerja Puskesmas Paal V Kota Jambi Tahun 2020 ( $\mathrm{p}=0,043)$. Hasil penelitian juga diperoleh nilai $\mathrm{OR}=4,0$, sehingga pengetahuan merupakan faktor risiko status gizi balita. Responden yang memiliki pengetahuan kurang baik berisiko 4 kali lebih besar memiliki balita status gizi kurang jika dibandingkan dengan responden yang memiliki pengetahuan baik.

Salah satu faktor penting yang mempengaruhi status gizi pada balita adalah faktor pengetahuan ibu tentang gizi pada balita. Kurangnya pengetahuan ibu tentang keragaman bahan dan keragaman jenis makanan akan menimbulkan terganggunya proses pertumbuhan dan perkembangan balita terutama perkembangan otak, oleh karena itu penting untuk ibu dalam memberikan asupan makanan yang bergizi kepada anaknya. Banyak orang tua terutama ibu yang tidak memperhatikan asupan nutrisi pada anak balitanya. Padahal anak usia balita rentan terhadap penyakit dan infeksi (Istiyani, 2013).

Menurut asumsi peneliti, ada hubungan antara pengetahuan dengan status gizi pada balita karena ibu yang berpengetahuan luas dan berpendidikan, tahu cara memenuhi gizi anakanya dan mampu menyiapkan makanan bergizi yang baik maka status gizi anak menjadi baik, begitu sebaliknya jika ibu tidak mengetahui cara memenuhi gizi anaknya maka status gizi anak menjadi kurang baik. Pengetahuan ibu yang baik tentang gizi seimbang anak adalahibu yang mengerti kebutuhan gizi dan mampu menyajikan menu atau mutrisi yang akan diberikn kepada anaknya, sehingga anaknya tercukupi gizinya.

Berdasarkan hasil penelitian menunjukkan tidak ada hubungan antara partisipasi ibu dalam posyandu dengan status gizi pada balita di wilayah kerja Puskesmas Paal V Kota Jambi Tahun 2020 ( $\mathrm{p}=1,000)$. Hasil penelitian ini tidak sejalan dengan penelitian yang dilakukan oleh Amrul Hasan dan Haris Kadarusman (2019) diperoleh hasil bahwa responden yang tidak memantau balita berisiko 10 kali lebih tinggi menderita gizi kurang jika dibandingkan dengan responden yang memantau balita.

Hasil penelitian ini menunjukkan bahwa tidak ada hubungan antara partisipasi ibu dalam posyandu dengan status gizi pada balita di wilayah kerja Puskesmas Paal V dikarenakan 97,9\% responden memliki partisipasi yang baik 
Journal of Healthcare Technology and Medicine Vol. 6 No. 2 Oktober 2020

Universitas Ubudiyah Indonesia

e-ISSN : 2615-109X

dalam kegiatan posyandu dan hanya 2,1\% yang memiliki partisipasi kurang baik dalam posyandu. Berdasarkan hasil penelitian menunjukkan ada hubungan antara pola asuh dengan status gizi pada balita di wilayah kerja Puskesmas Paal V Kota Jambi Tahun 2020 ( $p=0,037$ ). Hasil penelitian juga diperoleh nilai $\mathrm{OR}=6,6$, maka pola asuh merupakan faktor risiko terhadap status gizi balita. Responden yang memiliki pola asuh kurang baik berisiko 4,49 kali lebih besar memiliki balita status gizi kurang jika dibandingkan dengan responden yang memiliki pola asuh baik.

Hasil penelitian ini sejalan dengan penelitian yang dilakukan oleh Lilis Fauziah, Nurdin Rahman dan Hermiyanti (2017) di Kelurahan Taipa Kota Palu diperoleh nilai $\mathrm{OR}=3,2$, maka pola asuh merupakan faktor risiko status gizi balita. Responden yang memiliki pola asuh kurang baik berisiko lebih besar 3,2 kali lebih besar mempunyai balita yang mengalami gizi kurang.

Pola asuh orangtua menjadi sangat penting dalam proses perkembangan dan pertumbuhan anak baik secara fisik maupun psikis. Bukan hanya tuntutan yang diberikan oleh orangutan kepada anak, tetapi orangtua juga mendorong dan memotivasi anak untuk hal-hal yang positif buat anak yang nantinya akan sangat berguna untuk masa yang akan datang buat si anak. Banyak variasi dan model yang tentunya digunakan oleh orangtua dalam setiap mendidik dan mengasuh anaknya, yang tentunya pengaruh terhadap perilaku dan sikap anak berbeda-beda (Sulistyaningsih, 2011).

Menurut asumsi peneliti ada hubungan antara pola asuh dengan status gizi pada balita, semakin baik pola asuh yang diberikan maka semakin baik status gizi balita dan sebaliknya apabila ibu memberikan pola asuh yang kurang baik dalam pemberian makanan pada balita maka status gizi balita juga akan terganggu. Terdapat hubungan tersebut dikarenakan pengalaman ibu dalam mengasuh anak kurang baik. Responden yang berusia muda kemungkinan kurang memiliki pengalaman dalam mengasuh anak sehingga dalam merawat anak didasarkan pada pengalaman orang tua terdahulu. Selain itu, ibu membiarkan balitanya makan sendiri tanpa pendampingan sehingga jumlah atau porsi maupun jenis makanan yang dikonsumsi balita tidak dikontrol dengan baik. Frekuensi dan porsi makanan yang seharusnya menjadi perhatian jika diabaikan akan berdampak pada 
Journal of Healthcare Technology and Medicine Vol. 6 No. 2 Oktober 2020

Universitas Ubudiyah Indonesia

e-ISSN : 2615-109X

kesehatan balita sendiri karena makanan yang dikonsumsi tidak memadai untuk memenuhi aktivitas balita sehari-harinya. Disamping itu, menu makanan yang disajikan dalam satu minggu cenderung tidak bervariasi yang dapat menimbulkan kejenuhan pada balita dan sifat pilih-pilih makanan. Balita yang tidak terbiasa dengan variasi makanan lokal dapat menyebabkan balita menjadi pilih-pilih makanan sehingga pemenuhan zat gizi lainnya menjadi kurang. Kekurangan zat gizi yang berlangsung secara terus-menerus inilah yang dapat menyebabkan kurangnya berat badan balita.

Berdasarkan hasil penelitian menunjukkan ada hubungan antara penyakit infeksi dengan status gizi pada balita di wilayah kerja Puskesmas Paal V Kota Jambi Tahun 2020 ( $p=0,039)$. Hasil penelitian juga diperoleh nilai $\mathrm{OR}=6,6$, yang menunjukkan bahwa responden yang memiliki balita menderita penyakit infeksi berisiko lebih tinggi 6,6 kali memiliki balita status gizi kurang jika dibandingkan dengan responden yang memiliki balita tidak menderita penyakit infeksi.

Hasil penelitian ini sejalan dengan penelitian yang dilakukan oleh Sri Ningsi \& Risma (2017) di wilayah kerja Puskesmas Anreapi Kabupaten Polewali Mandar diperoleh nilai $\mathrm{OR}=6,5$; balita yang menderita penyakit infeksi berisiko sebesar 6,5 kali mengalami gizi kurang jika dibandingkan dengan balita yang tidak menderita penyakit infeksi.

Proses riwayat alami terjadinya suatu penyakit yang dietrapkan pada masalah gizi (kurang gizi) melalui bebagai tahap yaitu diawali dengan terjadinya interaksi antara penjamu, sumber penyakit dan lingkungan. Ketidakseimbangan antara ketiga faktor ini, misalnya ketidakcukupan zat gizi dalam tubuh maka simpanan zat gizi berkurang dan lama kelamaan simpanan menjadi habis. Apabila memasuki ambang teknis, proses itu berlanjut sehingga menyebabkan orang sakit (Supariasa, 2002).

Menurut asumsi ada hubungan antara penyakit infeksi dengan status gizi dalam penelitian ini dikarenakan penyakit infeksi dapat menyebabkan menurunnya nafsu makan pada saat balita sakit. Jika balita tidak makan maka asupan gizi menjadi tidak terpenuhi sehingga berat badan balita menjadi turun. Ada hubungan timbal balik antara asupan gizi dan kejadian infeksi. Kekurangan asupan berhubungan erat dengan tingginya kejadian penyakit diare, karena anak 
Journal of Healthcare Technology and Medicine Vol. 6 No. 2 Oktober 2020

Universitas Ubudiyah Indonesia

e-ISSN : 2615-109X

yang kurang gizi mungkin mengalami penurunan daya tahan tubuh dan dengan adanya penyakit infeksi menyebabkan anak tidak mempunyai nafsu makan. Akibatnya terjadi kekurangan makanan dan minuman yang masuk kedalam tubuh sehingga anak menderita kurang gizi.

Berdasarkan hasil penelitian menunjukkan ada hubungan antara tingkat risiko pencemaran jamban dengan status gizi pada balita di wilayah kerja Puskesmas Paal V Kota Jambi Tahun $2020(\mathrm{p}=0,021)$. Hasil penelitian juga diperoleh nilai $\mathrm{OR}=0,206$, yang menunjukkan bahwa responden yang memiliki sanitasi risiko sedang lebih rendah 0,206 kali memiliki balita status gizi kurang jika dibandingkan dengan responden yang memiliki sanitasi risiko rendah.

Keberadaan jamban yang tidak memenuhi standar secara teori berpotensi memicu timbulnya penyakit infeksi yang karena higiene dan sanitasi yang buruk (misalnya diare dan kecacingan) yang dapat menganggu penyerapan nutrisi pada proses pencernaan. Beberapa penyakit infeksi yang diderita bayi dapat menyebabkan berat badan bayi turun. Jika kondisi ini terjadi dalam waktu yang cukup lama dan tidak disertai dengan pemberian asupan yang cukup untuk proses penyembuhan maka dapat mengakibatkan stunting (Kemenkes RI, 2018).

Menurut asumsi peneliti ada hubungan antara tingkat risiko pencemaran jamban dengan status gizi balita dikarenakan jamban yang dimiliki oleh responden memiliki tingkat risiko sedang sehingga berpotensi untuk menimbulkan penyakit diare pada keluarga terutama pada balita, munculnya diare pada balita memiliki kecendrungan untuk terjadi gangguan pertumbuhan anak akibat makanan yang sulit terserap, sehingga balita memiliki status gizi kurang bahkan jika hal ini terjadi secara lama dapat mengakibatkan terjadinya stunting.

Berdasarkan hasil penelitian diketahui bahwa tidak ada hubungan antara tingkat risiko pencemaran sarana air bersih dengan status gizi pada balita di wilayah kerja Puskesmas Paal V Kota Jambi Tahun $2020(\mathrm{p}=1,000)$. Air bersih tidak berhubungan dengan status gizi pada balita maka variabel tingkat risiko pencemaran sarana air bersih bukan faktor risiko terhadap status gizi pada balita di wilayah kerja Puskesmas Paal V Kota Jambi.

Hasil penelitian ini sejalan dengan penelitian yang dilakukan oleh Indar Dwi Ningsih (2013) di Kelurahan Semanggi dan Sangkrah Kecamatan Pasar Kliwon 
Journal of Healthcare Technology and Medicine Vol. 6 No. 2 Oktober 2020

Universitas Ubudiyah Indonesia

e-ISSN : 2615-109X

diperoleh hasil bahwa tidak ada hubungan antara sanitasi lingkungan (akses air bersih) terhadap status gizi anak prasekolah di kelurahan Semanggi dan Sangkrah Kecamatan Pasar Kliwon ( $\mathrm{p}=0,502)$.

Hasil penelitian menunjukkan bahwa tidak ada hubungan antara tingkat risiko pencemaran sarana air bersih dengan status gizi balita, hal tersebut terkait dengan hasil penelitian dimana sebagian besar responden yaitu 70,8\% menggunakan air dari perpipaan dan hanya 29,2\% yang menggunakan sumur gali. Sanitasi perpipaan merupakan sumber air yang terlindungi sehingga mencegah terjadinya pencemaran dan mencegah terjadinya penyakit diare. Hasil penelitian juga menunjukkan bahwa responden yang memiliki tingkat risiko pencemaran sarana air bersih dengan risiko rendah sebesar $85,4 \%$ dan resiko sedang sebesar $14,6 \%$. Hal tersebut menunjukkan bahwa sebagian besar responden memiliki air bersih yang layak dan hanya sedikit yang memiliki akses air bersih yang tidak layak.

Tidak ada hubungan antara tingkat risiko pencemaran sarana air bersih dengan status gizi pada balita dalam penelitian ini dapat dikarenakan dari faktor lain yaitu pengetahuan orang tua, pola asuh, penyakit infeksi, sanitasi, sosial ekonomi dan sebagainya yang dalam hal ini dapat dikatakan bahwa masih banyak faktor yang dapat mempengaruhi dalam terpenuhinyaa status gizi anak.

\section{KESIMPULAN}

Hasil penelitian menunjukkan bahwa faktor risiko status gizi balita di wilayah kerja Puskesmas Paal V Kota Jambi adalah pengetahuan, pola asuh, penyakit infeksi dan tingkat risiko pencemaran jamban.

\section{SARAN}

1. Diharapkan kepada puskesmas untuk aktif dalam memberikan penyuluhan atau praktik langsung dengan menyediakan alat peraga atau leaflet yang mudah dipahami oleh ibu-ibu untuk meningkatkan pengetahuan ibu tentang gizi dan memberikan penyuluhan dalam menentukan jenis makanan yang akan dikonsumsi balita sehingga mampu meningkatkan kemampuan ibu dalam memberikan makanan pada balita. 
Journal of Healthcare Technology and Medicine Vol. 6 No. 2 Oktober 2020

Universitas Ubudiyah Indonesia

e-ISSN : 2615-109X

2. Diharapkan kepada Petugas Puskesmas untuk melakukan inspeksi jamban pada masyarakat secara rutin setiap 6 bulan sekali sehingga dapat mengetahui tingkat risiko jamban yang dimiliki oleh masyarakat.

\section{DAFTAR PUSTAKA}

Hasan.A \& Kadarusman.H .(2019). Akses ke Sarana Sanitasi Dasar sebagai Faktor Risiko Kejadian Stunting pada Balita Usia 6-59 Bulan.Jurnal kesehatan. Vol. 10(3)

Istiyani. 2013. Pola Asuh pada Balita Gizi Baik dan Gizi Buruk. Naskah Publikasi. Fakultas Ilmu Kesehatan. Universitas Muhammadiyah Surakarta, pp: 132-139.

Indar Dwi Ningsih. (2013). Hubungan Kesehatan Lingkungan Terhadap Status Gizi Anak Prasekolah Di Kelurahan Semanggi Dan Sangkrah Kecamatan Pasar Kliwon Surakarta. Naskah Publikasi. Universitas Muhammadiyah Surakarta

Kementerian Kesehatan RI. 2018. Buku Saku Pemantauan Status Gizi. Jakarta.

Lilis.F, Nurdin.R \& Hermiyanti. (2017).Faktor Risiko Kejadian Gizi Kurang Pada Balita Usia 24-59 Bulan Di Kelurahan Taipa Kota Palu. Medika Tadulako, Jurnal Ilmiah Kedokteran, Vol. 4 No. 3

Par'i, H.M. 2016. Penilaian Status Gizi Dilengkapi Proses Pola Asuhan Gizi Terstandar. Jakarta: EGC.

Setyawati, Hartini. 2018. Buku Ajar Dasar Ilmu Gizi Kesehatan Masyarakat. Ed.1, Cet. 1.Yogyakarta.

Sri Nengsi \& Risma. (2017). Hubungan Penyakit Infeksi Dengan Status Gizi Balita Diwilayah Kerja Puskesmas Anreapi Kabupaten Polewalimandar. Jurnal Kesehatan Masyarakat. Vol 3(1)

Sulistyaningsih. 2011. Posyandu dan Desa Siaga; Panduan untuk Bidan dan Kader. Yogyakarta: Nuha Medika

Supariasa. 2002. Penilaian Status Gizi. Jakarta: EGC

Tantejo B. dkk.2013. Hubungan Pengetahuan Tentang Gizi Dengan Status Gizi Pada Balita Di Wilayah Kerja Puskesmas XIII Koto Kampar. JOM.Volume.1, No.2, Oktober 2014 
Journal of Healthcare Technology and Medicine Vol. 6 No. 2 Oktober 2020

Universitas Ubudiyah Indonesia

e-ISSN : 2615-109X

UNICEF Indonesia. 2012. Ringkasan Kajian. UNICEF 